\title{
Orthogonal Experiments on Ozone Oxidation Denitration of Sintering Flue Gas
}

\author{
Yingxin Yang, Lu Zhong, Xueliang Xue, Jingling Hu, Xiaotu Hu, and Yong Liu \\ Guangdong J-Tech Environment Science Co., Ltd., Guangzhou 510663, China
}

\begin{abstract}
Ozone oxidation denitration process has become the most closely watched sintering flue gas denitration technology currently. In order to investigate the influence of different operating conditions on NO oxidation in practical engineering application of this technology, an ozone oxidation system was built, and sintering flue gas was extracted from the pipeline between the induced draft fan and the desulfurization tower. The influence of flue gas flow and inlet NO concentration on NO oxidation was investigated by orthogonal experiments. The results indicated that $\mathrm{NO}$ oxidation efficiency increased with the $\mathrm{O}_{3}$ yield of ozone generator and $\mathrm{O}_{3}$ dosage under any flue gas conditions. Under the same inlet $\mathrm{NO}$ concentration, NO oxidation efficiency decreased with the increase of flue gas flow. Under the same flue gas flow and $\mathrm{O}_{3}$ dosage, with the increase of inlet $\mathrm{NO}$ concentration, the $\mathrm{O}_{3}$ utilization rate increased while the average oxidation energy consumption of each NO molecule decreased, which was beneficial to promote the NO oxidation efficiency. In practical engineering application, the setting of $\mathrm{O}_{3}$ dosage should take into account both engineering design indicators and economy. Ozone oxidation denitration process could achieve NO oxidation efficiency higher than $90 \%$ through reasonable design, indicating a good industrial application prospect in the treatment of sintering flue gas.
\end{abstract}

\section{Introduction}

Nitrogen oxides $\left(\mathrm{NO}_{x}\right)$ is one of the major air pollutants discharged by steel industry. The $\mathrm{NO}_{x}$ generated by sintering process whose major components are $\mathrm{NO}(95 \%)$ and $\mathrm{NO}_{2}(5 \%)$ [1] accounts for $48 \%$ [2] of the whole steel smelting process. With the intensified requirements on ambient air quality, controlling $\mathrm{NO}_{x}$ emission from sintering flue gas has become the most important priority in steel industry. However, the performance of flue gas denitration technology implemented in steel industry is not satisfactory compared with other air pollution control technologies such as desulfurization.

At present, the technology combining ammoniaselective catalytic reduction $\left(\mathrm{NH}_{3}-\mathrm{SCR}\right)$ denitration with wet flue gas desulfurization (WFGD) has been widely used in coal-fired power plants. This combination could achieve high desulfurization and denitration efficiencies, but the optimal active temperature of catalysts in $\mathrm{NH}_{3}$ SCR process is $320 \sim 450^{\circ} \mathrm{C}$, and it exhibits disadvantages including high economic costs, catalyst poisoning, ammonia escape, and so on [3]. As a result, it is unsuitable for dealing with the sintering flue gas that is at low temperature $\left(120 \sim 180{ }^{\circ} \mathrm{C}\right)$ and high humidity (10 12\%). In addition, the composition of sintering flue gas is complicated, while the flue gas flow and concentrations are wildly fluctuating [4]. Therefore, it is urgent to develop a high efficiency flue gas desulfurization and denitration technology which does not involve catalytic reaction devices, and could adapt to characteristics of sintering flue gas.

Ozone oxidation denitration process incorporates the enhanced oxidation by $\mathrm{O}_{3}$ and the improved absorption of WFGD system, such that it is able to oxidize the insoluble NO into high-soluble nitrogen oxides (such as $\mathrm{NO}_{2}, \mathrm{NO}_{3}, \mathrm{~N}_{2} \mathrm{O}_{5}$, etc.) and remove them by the desulfurization facilities. It has become the most closely watched sintering flue gas denitration technology due to its good properties of low economic costs, broad applicable temperature range, high selectivity to $\mathrm{NO}$, and so on [5]. LoTO ${ }_{x}$ technology developed by BOC Gases [6] uses $\mathrm{O}_{2} / \mathrm{O}_{3}$ gas mixture to oxidize $\mathrm{NO}_{x}$ into highvalence state and two stage washing process with $\mathrm{CaCO}_{3} / \mathrm{NaOH}$ to realize desulfurization and denitration simultaneously. Finally the achieved $\mathrm{NO}_{x}$ removal efficiency is over $90 \%$. In the research conducted by Mok [5], after the exhaust gas passed through the ozonizing chamber and the absorber sequentially, $\mathrm{NO}_{x}$ removal efficiency of about $95 \%$ and $\mathrm{SO}_{2}$ removal efficiency of $100 \%$ were obtained. Similar results were observed by Wang [1] who found that $97 \%$ of $\mathrm{NO}$ and nearly $100 \%$ of $\mathrm{SO}_{2}$ can be removed simultaneously by alkaline washing tower after the injection of ozone.

The oxidation of $\mathrm{NO}$ is the key step to realize high $\mathrm{NO}_{\mathrm{x}}$ removal efficiency [1]. In order to investigate the influence of different operating conditions on NO oxidation in practical industrial application of ozone oxidation denitration process, an ozone oxidation system was built, and sintering flue gas was extracted from the pipeline between the induced draft fan and the

\footnotetext{
* Corresponding author: yangyx@gdj-tech.com
} 
desulfurization tower. The influence of flue gas flow and inlet NO concentration on NO oxidation was investigated by orthogonal experiments.

\section{Experiment part}

\subsection{Process description}

The on-site operation of ozone oxidation experiments were conducted at a steel-making plant in Tangshan, Hebei province. An ozone oxidation system was built, and sintering flue gas was extracted from the pipeline between the induced draft fan and the desulfurization tower at $30000 \mathrm{~m}^{3} / \mathrm{h}$. The temperature of flue gas was about $140^{\circ} \mathrm{C}$.

The $\mathrm{O}_{3}$ gas used in experiments was generated by an ozone generator (GUOLIN, CF-G-2-7kg) through dielectric barrier discharge (DBD) with an adjustable discharge power ranging from 13 to $45 \mathrm{~kW}$. $\mathrm{O}_{2}$ gas $(99.5 \%$ vol.) was used as the gas source of generator, and its rated consumption was $70 \mathrm{~kg} / \mathrm{h}\left(50 \mathrm{~m}^{3} / \mathrm{h}\right)$. The energy consumption of generator to generate $1 \mathrm{~kg} \mathrm{O}$ was $7.5 \mathrm{kWh}$. The rated $\mathrm{O}_{3}$ concentration and $\mathrm{O}_{3}$ yield of generator were $148 \mathrm{mg} / \mathrm{L}\left(50 \mathrm{~m}^{3} / \mathrm{h}\right.$ ) and $7 \mathrm{~kg} / \mathrm{h}$ (with an adjustable range from 10 to $100 \%$ ) respectively.

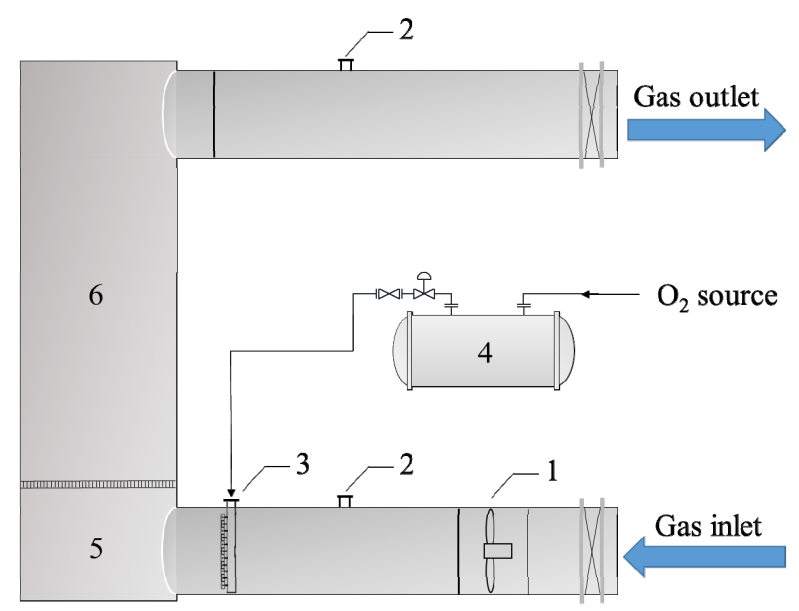

1- Axial flow fan; 2- Testing port;

3- Ozone feeding distributor; 4- Ozone generator;

5- Mixing chamber; 6- Oxidation chamber.

Fig. 1 Diagram of ozone oxidation system

As shown in figure $1, \mathrm{O}_{3}$ generated by ozone generator was injected into the flue gas by ozone feeding distributor at the inlet of the mixing chamber where $\mathrm{O}_{3}$ and flue gas were mixed thoroughly. The oxidation reactions between $\mathrm{O}_{3}$ and $\mathrm{NO}$ could be expressed by equation (1) to (3) [7]. And the mixed flue gas resided in the system for $0.6 \sim 1.0 \mathrm{~s}$. Finally, the oxidized flue gas entered into the desulfurization tower to remove the $\mathrm{SO}_{2}$ and $\mathrm{NO}_{x}$ from the flue gas simultaneously.

$$
\begin{aligned}
& \mathrm{O}_{3}+\mathrm{NO} \rightarrow \mathrm{NO}_{2}+\mathrm{O}_{2} \\
& \mathrm{O}_{3}+\mathrm{NO}_{2} \rightarrow \mathrm{O}_{2}+\mathrm{NO}_{3}
\end{aligned}
$$

$$
\mathrm{NO}_{2}+\mathrm{NO}_{3} \rightarrow \mathrm{N}_{2} \mathrm{O}_{5}
$$

\subsection{Setting of orthogonal experiment}

Orthogonal experiment was conducted to investigate the influence of flue gas flow (Q) and inlet NO concentration $\left(\mathrm{C}_{0}\right)$ on $\mathrm{NO}$ oxidation. The flue gas flow was set to $8500 \mathrm{~m}^{3} / \mathrm{h}, 16500 \mathrm{~m}^{3} / \mathrm{h}, 25000 \mathrm{~m}^{3} / \mathrm{h}$ corresponding to residence time of flue gas in the system for $6.2 \mathrm{~s}, 3.5 \mathrm{~s}, 2.1 \mathrm{~s}$, respectively. The inlet $\mathrm{NO}$ concentration was set to $107 \mathrm{mg} / \mathrm{m}^{3}, 188 \mathrm{mg} / \mathrm{m}^{3}, 241$ $\mathrm{mg} / \mathrm{m}^{3}$, respectively. The combinations of two factors in the orthogonal experiments have shown in table 1.

Table 1. Setting of orthogonal experiment

\begin{tabular}{|c|c|c|}
\hline Sequence number & $\mathrm{C}_{0}\left(\mathrm{mg} / \mathrm{m}^{3}\right)$ & $\mathrm{Q}\left(\mathrm{m}^{3} / \mathrm{h}\right)$ \\
\hline 1 & 107 & 8500 \\
\hline 2 & 107 & 16500 \\
\hline 3 & 107 & 25000 \\
\hline 4 & 188 & 8500 \\
\hline 5 & 188 & 16500 \\
\hline 6 & 188 & 25000 \\
\hline 7 & 241 & 8500 \\
\hline 8 & 241 & 16500 \\
\hline 9 & 241 & 25000 \\
\hline
\end{tabular}

\subsection{Evaluation of NO oxidation efficiency}

The $\mathrm{O}_{3}$ concentration at the outlet of ozone generator was monitored online by ozone concentration detector, and $\mathrm{O}_{3}$ yield was calculated by the control system of generator. The NO concentration at the inlet and outlet of ozone oxidation system was measured by an exhaust gas analyser (Testo 350). Based on the monitoring results, the NO oxidation efficiency can be estimated by equation (4).

$$
\eta_{N O}=\frac{[\mathrm{NO}]_{\text {in }}-[\mathrm{NO}]_{\mathrm{out}}}{[\mathrm{NO}]_{\text {in }}} \times 100 \%
$$

In equation (4), $[\mathrm{NO}]_{\text {in }}$ and $[\mathrm{NO}]_{\text {out }}$ represent the $\mathrm{NO}$ concentration at the inlet and outlet of system respectively.

\section{Results and discussion}

\subsection{Influence of flue gas flow on NO oxidation}

\subsubsection{Influence of ozone yield on NO oxidation under different flue gas flow}

As shown in figure 2, under the same inlet NO concentration, $\mathrm{NO}$ oxidation efficiencies of different flue gas flow increased along with the $\mathrm{O}_{3}$ yield of ozone generator. And under the same $\mathrm{O}_{3}$ yield, $\mathrm{NO}$ oxidation efficiency decreased with the increase of flue gas flow. 

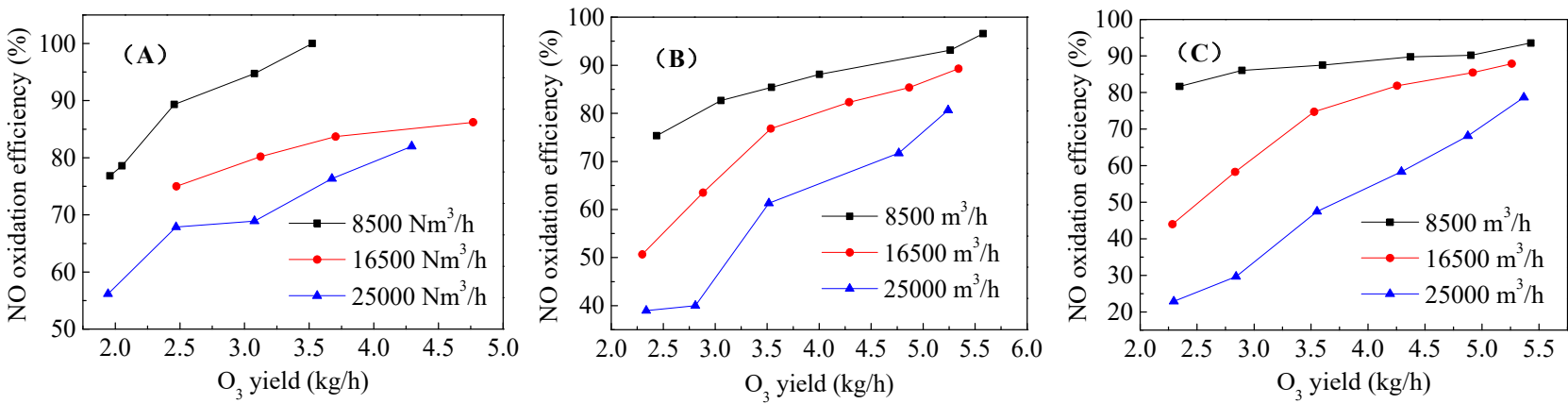

Fig. 2 Influence of ozone yield on NO oxidation efficiency under different flue gas flow (A) $\mathrm{C}_{0}(\mathrm{NO})=107 \mathrm{mg} / \mathrm{m}^{3} ;(B) \mathrm{C}_{0}(\mathrm{NO})=188 \mathrm{mg} / \mathrm{m}^{3}$; (C) $\mathrm{C}_{0}(\mathrm{NO})=241 \mathrm{mg} / \mathrm{m}^{3}$
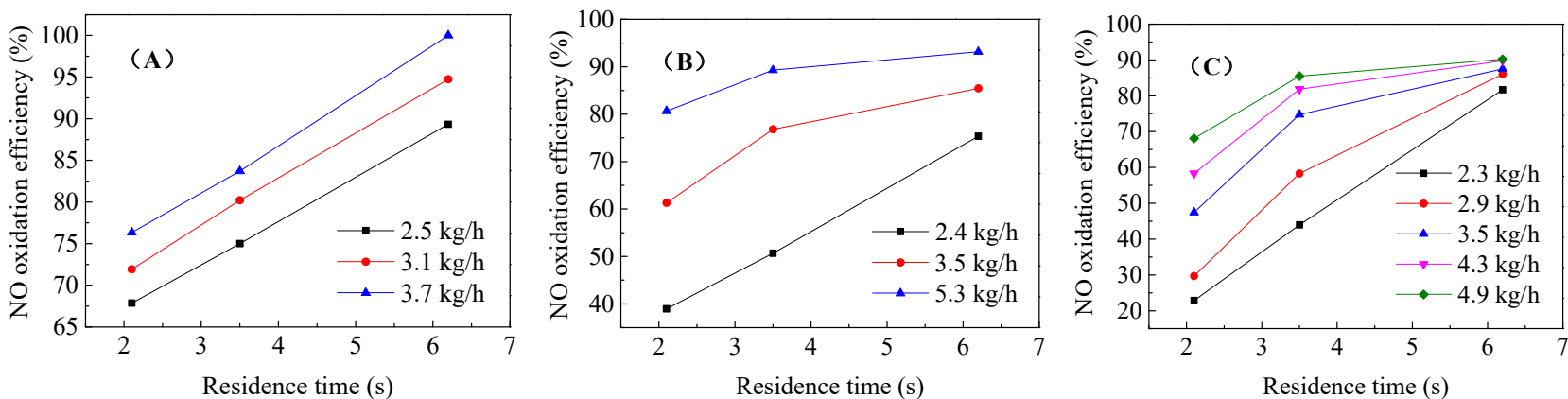

Fig. 3 Influence of retention time on $\mathrm{NO}$ oxidation efficiency under different ozone yield (A) $\mathrm{Co}_{0}(\mathrm{NO})=107 \mathrm{mg} / \mathrm{m}^{3}$; (B) $\mathrm{C}_{0}(\mathrm{NO})=188 \mathrm{mg} / \mathrm{m}^{3}$; (C) $\mathrm{C}_{0}(\mathrm{NO})=241 \mathrm{mg} / \mathrm{m}^{3}$
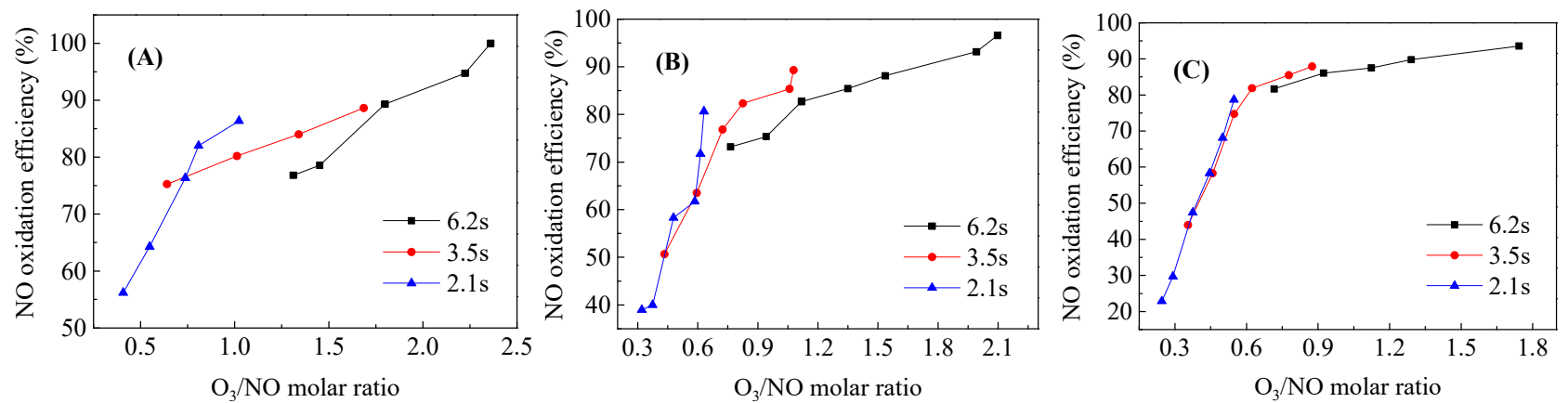

Fig. 4 Influence of ozone dosage on NO oxidation efficiency under different flue gas flow (A) $\mathrm{C}_{0}(\mathrm{NO})=107 \mathrm{mg} / \mathrm{m}^{3}$; (B) $\mathrm{C}_{0}(\mathrm{NO})=188 \mathrm{mg} / \mathrm{m}^{3}$; (C) $\mathrm{Co}_{0}(\mathrm{NO})=241 \mathrm{mg} / \mathrm{m}^{3}$

different $\mathrm{O}_{3}$ yield decreased along with the residence

\subsubsection{Influence of residence time on NO oxidation under different ozone yield}

Flue gas flow determined the residence time of flue gas in the ozone oxidation system, which would influence the NO oxidation effect. Numerous studies have shown that with a certain amount of $\mathrm{O}_{3}$ dosage, the longer residence time was, the more beneficial it would be to NO oxidation. On the other hand, when the residence time was fixed, the more excess of $\mathrm{O}_{3}$ dosage, the higher NO oxidation efficiency would be.

In this investigation, when the flue gas flow was $8500 \mathrm{~m}^{3} / \mathrm{h}, 16500 \mathrm{~m}^{3} / \mathrm{h}, 25000 \mathrm{~m}^{3} / \mathrm{h}$, the corresponding residence time of flue gas in the system was $6.2 \mathrm{~s}, 3.5 \mathrm{~s}$, $2.1 \mathrm{~s}$, respectively. As shown in figure 3, under the same inlet NO concentration, NO oxidation efficiencies of time. And under the same residence time, NO oxidation efficiency increased with the $\mathrm{O}_{3}$ yield.

\subsubsection{Influence of ozone dosage on NO oxidation under different residence time}

When the inlet $\mathrm{NO}$ concentration and $\mathrm{O}_{3}$ yield were fixed, the longer residence time of flue gas in the system was, the greater $\mathrm{O}_{3} / \mathrm{NO}$ molar ratio was, the more beneficial it would be to promote NO oxidation effect. As shown in figure 4, under the same inlet NO concentration, NO oxidation efficiencies of different residence time increased along with $\mathrm{O}_{3} / \mathrm{NO}$ molar ratio. Compared to residence time of $2.1 \mathrm{~s}$ and $3.5 \mathrm{~s}$, the $\mathrm{O}_{3} / \mathrm{NO}$ molar ratio and $\mathrm{NO}$ oxidation efficiency under residence time of $6.2 \mathrm{~s}$ were much higher. 

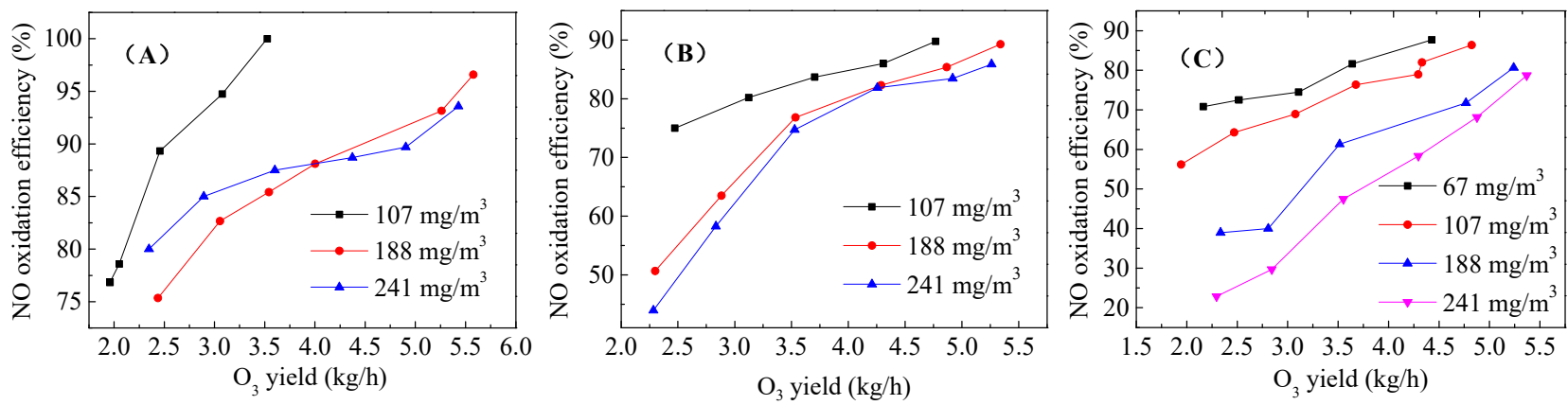

Fig. 5 Influence of ozone yield on NO oxidation efficiency under different inlet NO concentration (A) $Q=8500 \mathrm{~m}^{3} / \mathrm{h}$; (B) $\mathrm{Q}=16500 \mathrm{~m}^{3} / \mathrm{h}$; (C) $\mathrm{Q}=25000 \mathrm{~m}^{3} / \mathrm{h}$
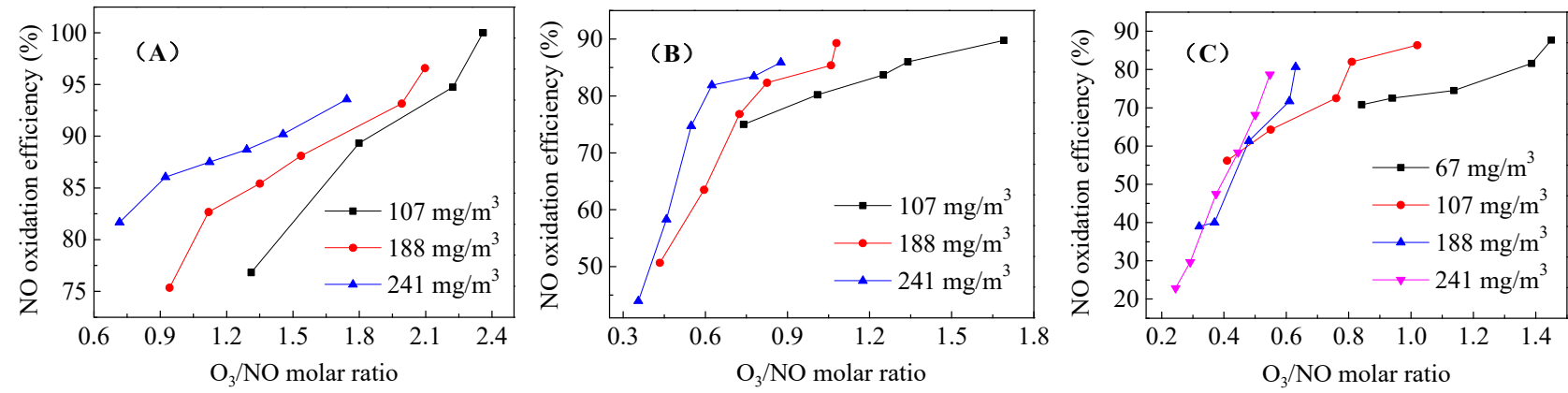

Fig. 6 Influence of ozone dosage on NO oxidation efficiency under different inlet NO concentration (A) $\mathrm{Q}=8500 \mathrm{~m}^{3} / \mathrm{h}$; (B) $\mathrm{Q}=16500 \mathrm{~m}^{3} / \mathrm{h}$; (C) $\mathrm{Q}=25000 \mathrm{~m}^{3} / \mathrm{h}$

ratio was about 1.3 , the $\mathrm{O}_{3}$ utilization rate was $58.58 \%$,

\subsection{Influence of inlet NO concentration on NO oxidation}

\subsubsection{Influence of ozone yield on NO oxidation under different inlet NO concentration}

As shown in figure 5, NO oxidation efficiencies of different inlet $\mathrm{NO}$ concentration increased along with $\mathrm{O}_{3}$ yield. And under the same $\mathrm{O}_{3}$ yield, $\mathrm{NO}$ oxidation efficiency decreased generally with the increase of inlet NO concentration. This could be ascribed to the lower $\mathrm{O}_{3} / \mathrm{NO}$ molar ratio under high inlet $\mathrm{NO}$ concentration, if the flue gas flow and $\mathrm{O}_{3}$ yield was fixed.

\subsubsection{Influence of ozone dosage on NO oxidation under different inlet NO concentration}

As shown in figure 6, under the same flue gas flow, NO oxidation efficiencies at different inlet $\mathrm{NO}$ concentration increased along with $\mathrm{O}_{3} / \mathrm{NO}$ molar ratio. Meanwhile under the same $\mathrm{O}_{3} / \mathrm{NO}$ molar ratio, $\mathrm{NO}$ oxidation efficiency increased with the inlet NO concentration.

\subsubsection{Influence of ozone dosage on ozone utilization rate under different inlet NO concentration}

As shown in figure 7, $\mathrm{O}_{3}$ utilization rate of different inlet $\mathrm{NO}$ concentration decreased along with the increase of $\mathrm{O}_{3} / \mathrm{NO}$ molar ratio. And under the same $\mathrm{O}_{3} / \mathrm{NO}$ molar ratio, the higher inlet $\mathrm{NO}$ concentration was, the higher $\mathrm{O}_{3}$ utilization rate would be. When the $\mathrm{O}_{3} / \mathrm{NO}$ molar $62.27 \%, 69.15 \%$ at the inlet NO concentration of 107 $\mathrm{mg} / \mathrm{m}^{3}, 188 \mathrm{mg} / \mathrm{m}^{3}, 241 \mathrm{mg} / \mathrm{m}^{3}$, respectively.

This indicated that in practical engineering application, the increase of $\mathrm{O}_{3}$ dosage was beneficial to $\mathrm{NO}$ oxidation, but it would reduce the $\mathrm{O}_{3}$ utilization rate. One possible reason was that in practical oxidation process, $\mathrm{O}_{3}$ oxidized generated $\mathrm{NO}_{2}$ into high-valence nitrogen oxides (such as $\mathrm{NO}_{3}, \mathrm{~N}_{2} \mathrm{O}_{5}$, etc.) or reacted with other components in flue gas, which made some of $\mathrm{O}_{3}$ not be used for NO oxidation.

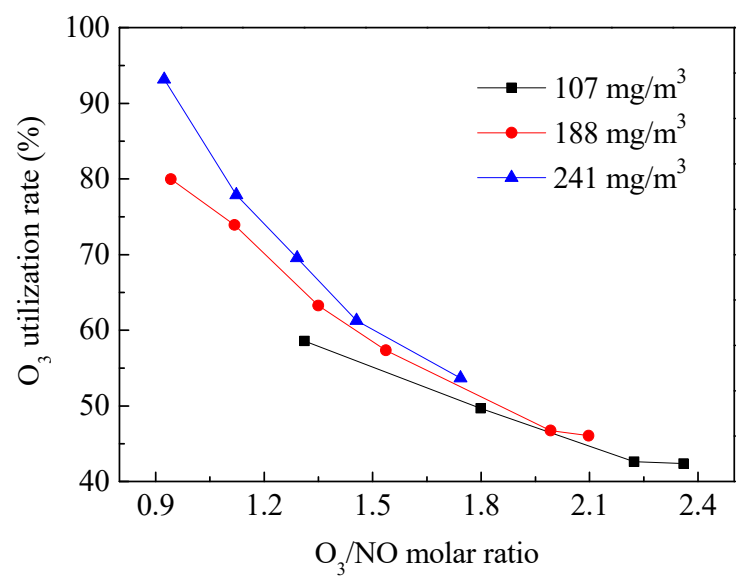

Fig. 7 Influence of ozone dosage on ozone utilization rate under different inlet $\mathrm{NO}$ concentration

$\left(\mathrm{Q}=8500 \mathrm{~m}^{3} / \mathrm{h}\right)$

3.2.4 Influence of ozone dosage on oxidation energy consumption under different inlet NO concentration 
As shown in figure 8 , when the flue gas flow was 8500 $\mathrm{m}^{3} / \mathrm{h}$, oxidation energy consumptions under different inlet NO concentration decreased along with the increase of $\mathrm{O}_{3} / \mathrm{NO}$ molar ratio. Meabwhile under the same $\mathrm{O}_{3} / \mathrm{NO}$ molar ratio, the higher inlet NO concentration was, the lower average oxidation energy consumption would be. Specifically, when the $\mathrm{O}_{3} / \mathrm{NO}$ molar ratio was about 1.3 , average oxidation energy consumption of each $\mathrm{NO}$ molecule was $0.04865 \mathrm{eV}, 0.04375 \mathrm{eV}, 0.04214 \mathrm{eV}$ at the inlet NO concentration of $107 \mathrm{mg} / \mathrm{m}^{3}, 188 \mathrm{mg} / \mathrm{m}^{3}$, $241 \mathrm{mg} / \mathrm{m}^{3}$, respectively.

According to the above test results, under the same flue gas flow rate and $\mathrm{O}_{3} / \mathrm{NO}$ molar ratio, with the increase of inlet $\mathrm{NO}$ concentration, the $\mathrm{O}_{3}$ utilization rate increased while the average oxidation energy consumption of each NO molecule decreased, which was beneficial to promote NO oxidation efficiency.

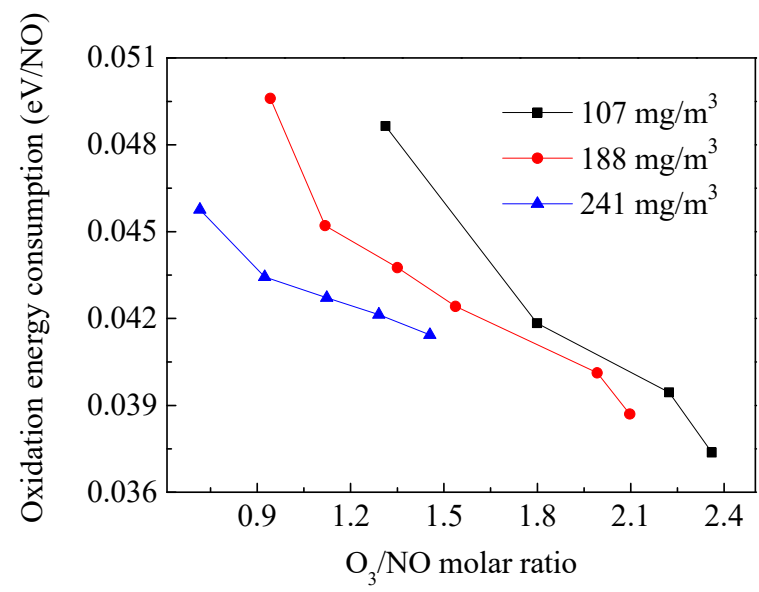

Fig. 8 Influence of ozone dosage on oxidation energy consumption under different inlet $\mathrm{NO}$ concentration

$$
\left(\mathrm{Q}=8500 \mathrm{~m}^{3} / \mathrm{h}\right)
$$

Table 2. Results of orthogonal experiment

\begin{tabular}{|c|c|c|}
\hline$C_{0}\left(\mathrm{mg} / \mathrm{m}^{3}\right)$ & $Q\left(\mathrm{~m}^{3} / \mathrm{h}\right)$ & $\eta_{N O}(\%)$ \\
\hline 107 & 8500 & $77 \sim 100$ \\
\hline 107 & 16500 & $75 \sim 90$ \\
\hline 107 & 25000 & $56 \sim 86$ \\
\hline 188 & 8500 & $75 \sim 96$ \\
\hline 188 & 16500 & $50 \sim 89$ \\
\hline 188 & 25000 & $33 \sim 80$ \\
\hline 241 & 8500 & $81 \sim 94$ \\
\hline 241 & 16500 & $44 \sim 86$ \\
\hline 241 & 25000 & $23 \sim 79$ \\
\hline
\end{tabular}

\subsection{Results of orthogonal experiment}

In this investigation, the influence of flue gas flow and inlet NO concentration on NO oxidation was investigated. As shown in table 2, ozone oxidation denitration process could achieve NO oxidation efficiency higher than $90 \%$ in the practical engineering application through reasonable design, indicating a good industrial application prospect in the treatment of sintering flue gas.

\section{Conclusions}

Following conclusions could be drawn from the experimental results:

(1) $\mathrm{NO}$ oxidation efficiency increased with the $\mathrm{O}_{3}$ yield of ozone generator and $\mathrm{O}_{3}$ dosage under any flue gas conditions.

(2) Under the same inlet NO concentration, NO oxidation efficiency decreased with the increase of flue gas flow which was equivalent to the decrease of residence time of flue gas in the ozone oxidation system.

(3) Under the same flue gas flow and $\mathrm{O}_{3}$ yield, $\mathrm{NO}$ oxidation efficiency decreased with the increase of inlet NO concentration.

(4) Under the same flue gas flow and $\mathrm{O}_{3}$ dosage, with the increase of inlet $\mathrm{NO}$ concentration, the $\mathrm{O}_{3}$ utilization rate increased while the average oxidation energy consumption of each NO molecule decreased, which was beneficial to promote the NO oxidation efficiency.

(5) In practical engineering application, the increase of $\mathrm{O}_{3}$ dosage could reduce average oxidation energy consumption of each NO molecule which was beneficial to $\mathrm{NO}$ oxidation, but it would reduce the $\mathrm{O}_{3}$ utilization rate. Therefore, the setting of $\mathrm{O}_{3}$ dosage should take into account both engineering design indicators and economy.

(6) Ozone oxidation denitration process could achieve NO oxidation efficiency higher than $90 \%$ in the practical engineering application through reasonable design, indicating a good industrial application prospect in the treatment of sintering flue gas.

\section{Acknowledgements}

The authors gratefully acknowledge financial support by Science and Technology Plan Project of Guangdong Province, China (No. 2017B090901057).

\section{References}

1. Z.H. Wang, J.H. Zhou, J.R. Fan, Y.Q. Zhu, Z.C. Wen, J.Z. Liu, K.F. Cen, Fuel Process. Technol 88, 817 (2007)

2. L.R. Zhou, C.B. Gao, S.B. Yang, CEPI 192, 33 (2014)

3. R.K. Srivastavam, W.N.D. Grano, S. Khan, ENVIRON PROG 24, 181(2005)

4. J. Huang, Gdchem 43, 138 (2016)

5. Y.S. Mok, H. Lee, Fuel Process. Technol 87, 591 (2006)

6. BOC GASES, 2000 Conference on Selective Catalytic and Non-Catalytic Reduction for $\mathrm{NO}_{x}$ control (US DOE, PA, 2000)

7. Z.H. Wang, J.H Zhou, J.R. Fan, K.F Cen, Energy Fuels 20, 2432 (2006) 